\title{
The Statutory Case against Off-Label Promotion
}

\author{
Nathan Cortez†
}

\section{INTRODUCTION}

One of the most vexing problems in drug and device regulation is "off-label" promotion-when a company markets uses for a product that have not been approved by the US Food and Drug Administration (FDA). Off-label use can range from conspicuous (prescribing a product for an unapproved medical condition or patient group) to more subtle (prescribing beyond the approved dosage, duration, or any other parameter set forth in the approved labeling). The challenge posed by off-label promotion derives from a well-established dichotomy: the FDA has jurisdiction to regulate manufacturers and the claims they make about their products, but has no jurisdiction to regulate the practice of medicine or physicians' prescribing behavior. ${ }^{1}$ This dichotomy not only creates the temptation for companies to promote off-label uses, but also creates a regulatory conundrum for the FDA.

The stakes are considerable. Companies earn billions from off-label prescriptions, as physicians may prescribe products "independently from, and occasionally in defiance of, the approved labeling." 2 Such prescribing can be critical in certain therapeutic areas, particularly those in which research findings greatly outpace the FDA approval process. ${ }^{3}$ As such, off-label uses can be common and evidence based. ${ }^{4}$ Indeed, off-label uses can even constitute the standard of care in disciplines like oncology, neurology,

$\dagger$ Adelfa Botello Callejo Endowed Professor of Law in Leadership and Latino Studies, Gerald J. Ford Research Fellow, Associate Dean for Research, Southern Methodist University, Dedman School of Law. I thank Rachel Freeman and Cassie DuBay for excellent research assistance.

1 See 21 USC $\$ 396$.

2 Daniel Carpenter, Reputation and Power: Organizational Image and Pharmaceutical Regulation at the FDA 617 (Princeton 2010).

3 See, for example, Amy P. Abernethy, et al, Systematic Review: Reliability of Compendia Methods for Off-Label Oncology Indications, 150 Annals Internal Med 336, 336, 342 (2009).

4 See Buckman Co v Plaintiffs' Legal Committee, 531 US 341, 350 (2001); Aaron S. Kesselheim and Michelle M. Mello, Prospects for Regulation of Off-Label Drug Promotion in an Era of Expanding Commercial Speech Protection, in Holly Fernandez Lynch and I. 
and psychiatry. For example, off-label uses are so widespread in oncology ${ }^{5}$ that federal law requires Medicare and Medicaid to reimburse for off-label uses of anticancer drugs if the use appears in an official medical compendium. ${ }^{6}$

On the other hand, off-label uses also can be dangerous, can be based on dubious evidence, and can inflate health spending. A 2006 study found that 73 percent of off-label uses by office-based physicians "had little or no scientific support," 7 and a 2012 study found that 79 percent of off-label uses by primary care physicians "lacked strong scientific evidence." 8 Thus, many worry that offlabel use can expose patients to considerable risks without corresponding benefits. ${ }^{9} \mathrm{~A}$ more recent study found that off-label uses were associated with a 44 percent greater likelihood of adverse events than approved uses. ${ }^{10}$ Off-label promotion has led to "widespread patient morbidity and mortality" for patients prescribed drugs like rofecoxib (Vioxx), rosiglitazone (Avandia), and paroxetine (Paxil), among others. ${ }^{11}$

As such, companies have paid tens of billions over the last two decades to settle allegations of illegal off-label promotion. ${ }^{12}$ In fact, most major drug and device firms have settled such cases. ${ }^{13}$ At the same time, the FDA has been admonished by Congress, academics, and the media for not doing more to regulate off-label promotion. ${ }^{14}$

Glenn Cohen, eds, FDA in the Twenty-First Century: The Challenges of Regulating Drugs and New Technologies 184, 185-86 (Columbia 2015).

5 See, for example, Michael Soares, "Off-Label" Indications for Oncology Drug Use and Drug Compendia: History and Current Status, 1 J Oncology Prac 102, 104 (2005).

$6 \quad$ See 42 USC $\$ \$ 1395 x(\mathrm{t})(2), 1396 \mathrm{r}-8(\mathrm{~g})(1)(\mathrm{B})(\mathrm{i}),(\mathrm{k})(6)$.

7 David C. Radley, Stan N. Finkelstein, and Randall S. Stafford, Off-Label Prescribing among Office-Based Physicians, 166 Archives Internal Med 1021, 1024 (2006).

8 Tewodros Eguale, et al, Drug, Patient, and Physician Characteristics Associated with Off-Label Prescribing in Primary Care, 172 Archives Internal Med 781, 785 (2012).

9 See Kesselheim and Mello, Prospects for Regulation of Off-Label Drug Promotion at 186 (cited in note 4); Henry A. Waxman, A History of Adverse Drug Experiences: Congress Had Ample Evidence to Support Restrictions on the Promotion of Prescription Drugs, 58 Food \& Drug L J 299, 305-306 (2003).

10 Tewodros Eguale, et al, Association of Off-Label Drug Use and Adverse Drug Events in an Adult Population, 176 JAMA Internal Med 55, 58 (2016).

11 Kesselheim and Mello, Prospects for Regulation of Off-Label Drug Promotion at 186-87 (cited in note 4).

12 Sammy Almashat, Sidney M. Wolfe, and Michael Carome, Twenty-Five Years of Pharmaceutical Industry Criminal and Civil Penalties: 1991 through 2015 *4-6 (Public Citizen, Mar 31, 2016), archived at http://perma.cc/3B25-73BY.

13 See id at *47-49 (listing the amount and size of fines paid by pharmaceutical companies from 1991 to 2015 ).

14 Carpenter, Reputation and Power at 618 (cited in note 2). 
Given the stakes, then, it is surprising that the Federal Food, Drug, and Cosmetic Act ${ }^{15}$ (FDCA) "do[es] not expressly prohibit the promotion or marketing of drugs for off-label use." 16 Others have also questioned the statutory basis for the prohibition. ${ }^{17}$ The FDA itself notes that "[p]romoting an approved drug for off-label uses is not itself a prohibited act under the FDCA, nor is it an element of any prohibited act." 18 Instead, the FDA argues, offlabel promotion "plays an evidentiary role in determining whether a drug is misbranded." 19

Nevertheless, almost no one has seriously undertaken the statutory question: Does the FDCA support the FDA's functional ban on off-label promotion? ${ }^{20}$ This Essay answers yes. Although the phrases "off-label" and "extra-label" are mentioned only once each in Title 21 , both in glancing ways, ${ }^{21}$ I find that multiple sections of the FDCA either assume or contemplate a ban on off-label promotion. I also find, using various tools of statutory construction, that the FDCA as a whole depends on the ban. Without it, significant portions of the statute would be hollow or even nonsensical, and the FDA's approval schemes- the lodestar of medical product regulation-would collapse under their own weight.

The statutory case against off-label promotion, then, is quite complex, and requires a fair bit of description of the statute, the FDA's logic, and how both evolved. The government must tailor its statutory logic depending on whether the off-label promotion qualifies as "labeling," "advertising," or something else, such as oral statements. Part I, then, describes the many faces of promotion, before turning to the detailed statutory logic that some offlabel promotion qualifies as labeling (Part II), as advertising

\footnotetext{
1552 Stat 1040 (1938), codified at 21 USC $\S 301$ et seq.

16 United States v Caronia, 703 F3d 149, 154 (2d Cir 2012) (quotation marks omitted).

17 See generally Terry S. Coleman, Origins of the Prohibition against Off-Label Promotion, 69 Food \& Drug L J 161 (2014).

18 Brief and Special Appendix for the United States, United States v Caronia, Nos 09-5006-cr(L), 10-0750(CON), *51 (2d Cir filed Oct 8, 2010) (available on Westlaw at 2010 WL 6351497) ("Caronia Brief").

19 Id.

20 Terry Coleman provides by far the most probing analysis of the statutory basis for the prohibition, but focuses on its historical origins and does not apply the tools of statutory construction. See generally Coleman, 69 Food \& Drug L J 161 (cited in note 17).

21 Only one section of Title 21 uses the phrase "off-label," in reference to a requirement that pediatric drug studies disclose both the "labeled and off-labeled" indications being studied. 21 USC $\$ 355 \mathrm{a}(\mathrm{f})(6)(\mathrm{B})$. The phrase "extra-label" is used once, in reference to labeling for certain unapproved but legally marketed animal drugs. 21 USC $\S 360 \mathrm{ccc}-1(\mathrm{~h})(1)$.
} 
(Part III), or as oral statements (Part IV), respectively. The payoff, I hope, is a concise application of the tools of construction in Part V. In short, the statutory case against off-label promotion is complicated but compelling.

\section{THE MANY FACES of Promotion}

Off-label promotion can take many forms. Because drug and device markets can be highly competitive, firms have devised ever more creative ways to promote their products. The classic scenario is "detailing," when a sales representative visits a physician's office to discuss a product in person, sometimes leaving behind written materials. ${ }^{22}$ Beyond detailing, firms have used continuing medical education (CME) events ${ }^{23}$ and paid for meals, travel, or entertainment to promote products off-label. ${ }^{24}$ Companies have also paid prescribers as speakers, consultants, advisors, or preceptors in order to suggest off-label uses for their products. 25 Even more questionable practices include funding sham educational and research "grants" that involve unapproved uses, or even hiring ghostwriters to publish journal articles discussing offlabel uses under the name of a respected "thought leader." 26

And then, of course, there is the menu of more traditional advertisements via television, radio, and print, which are often used as vehicles for suggesting off-label uses. More recently, the FDA has confronted companies online, where they use Internet advertising and social media to suggest off-label uses for their products. For example, companies have purchased sponsored links and search engine terms that suggest unapproved uses. ${ }^{27}$

22 See Stephanie M. Greene, FDA Prohibitions on Off-Label Marketing Do Not Violate Drug Manufacturers' First Amendment Rights, in Stephanie M. Greene and Lars Noah, Debate, Off-Label Drug Promotion and the First Amendment, 162 U Pa L Rev Online 239, 241 (2014).

23 Lars Noah, Permission to Speak Freely?, in Greene and Noah, Debate, $162 \mathrm{U}$ Pa L Rev Online at 248, 251 (cited in note 22).

24 See Duff Wilson, Novartis Settles Off-Label Marketing Case over 6 Drugs for $\$ 422.5$ Million (NY Times, Sept 30, 2010), available at http://nyti.ms/1PDkgPR (visited Sept 14, 2016) (Perma archive unavailable).

25 See, for example, id.

26 See Carl Elliott, The Secret Lives of Big Pharma's 'Thought Leaders' (Chronicle of Higher Education, Sept 12, 2010), archived at http://perma.cc/FX9G-XKL8.

27 See, for example, Jared A. Favole, FDA Warns Drug Firms over Internet Ads (Wall St J, Apr 4, 2009), online at http://www.wsj.com/articles/SB123879766861188121 (visited Sept 1, 2016) (Perma archive unavailable); Scott Gottlieb, FDA Regulates Internet Search (Forbes, Feb 15, 2013), available at http://onforb.es/11L1P7L (last visited Sept 14, 2016) (Perma archive unavailable). 
Finally, companies frequently distribute to prescribers medical reference texts and journal article reprints that discuss offlabel uses-which are not labeling or advertising when written, but may transform into such if used by the manufacturer that way.

Thus, virtually every form of promotion is a potential vessel for off-label messages. Yet, regardless of the form, rarely is the message a singular, isolated event; typically it occurs as part of a broader marketing scheme. ${ }^{28}$ The question for the government, then, is whether these messages qualify as labeling, advertising, or something else under the FDCA. The next three Parts (II-IV) describe the statutory logic.

\section{OFF-LABEL PROMOTION VIA LABELING}

According to the FDA, off-label promotion via "labeling" can violate both the new drug and misbranding sections of the statute. An important preface is that labeling is defined very broadly to cover a wide variety of statements or claims made by or on behalf of the manufacturer, in a wide variety of contexts. The FDCA defines "labeling" as "all labels and other written, printed, or graphic matter (1) upon any article or any of its containers or wrappers, or (2) accompanying such article." ${ }_{29}$ The latter clause is particularly important. Several early court decisions-including some that predated the 1938 Act ${ }^{30}$-interpreted "accompanying" to include materials that supplement or explain a product, even if distributed separately from it. ${ }^{31}$ In fact, after Congress passed the 1906 Pure Food and Drugs Act, ${ }^{32}$ companies frequently removed controversial product claims from packaging and distributed them separately via brochures or circulars to evade FDA jurisdiction, which under the 1906 Act was limited to packaging. ${ }^{3}$

\footnotetext{
28 Nathan Cortez, Can Speech by FDA-Regulated Firms Ever Be Noncommercial?, 37 Am J L \& Med 388, 413 (2011).

29 Federal Food, Drug, and Cosmetic Act (FDCA) § 201(m), 52 Stat 1040, 1041 (1938), codified at 21 USC $\$ 321(\mathrm{~m})$.

30 See, for example, Seven Cases of Eckman's Alternative v United States, 239 US $510,517-18$ (1916) (discussing how putting false claims in an accompanying circular for a product is still within reach of lawmaking power).

31 See Kordel v United States, 335 US 345, 349-50 (1948); United States v Urbuteit, 335 US 355, 356-57 (1948); V.E. Irons, Inc v United States, 244 F2d 34, 39 (1st Cir 1957).

32 Pub L No 59-384, 34 Stat 768 (1906).

33 Coleman, 69 Food \& Drug L J at 178-79 (cited in note 17).
} 
As concerns grew over companies giving false or misleading materials to physicians, ${ }^{34}$ the FDA defined "labeling" more broadly by rule. ${ }^{35}$ Today, the FDA defines "labeling" as virtually any "printed, audio, or visual matter" that describes a drug and is "disseminated by or on behalf of [the] manufacturer." 36

Defining "labeling" broadly is critical to the FDA's argument that off-label promotion violates the FDCA. As construed by courts, the content of the material determines whether it is labeling. Indeed, a recent case found that a company press release constituted labeling. ${ }^{37}$ If off-label promotion qualifies as labeling, the FDA can argue that the company violates the FDCA by introducing an unapproved "new drug" into interstate commerce, by misbranding the product, or both.

\section{A. The "New Drug" Provisions}

In some cases, the government alleges that off-label promotion violates the "new drug" provisions of the FDCA. Section 301(d) prohibits unapproved new drugs from being introduced into interstate commerce, ${ }^{38}$ and $\$ 505(\mathrm{a})$ bans any "new drug" not approved by FDA. ${ }^{39}$ Section 201(p), in turn, defines "new drug" to include any drug that the FDA has not approved "for use under the conditions prescribed, recommended, or suggested in the labeling." 40 Reference to the labeling here makes it difficult for the FDA to use the new drug provisions to prosecute off-label

34 See Part 22: Administered Prices in the Drug Industry (The Food and Drug Administration: Dr. Henry Welch), Hearings before the Subcommittee on Antitrust and Monopoly of the Committee on the Judiciary, United States Senate, 86th Cong, 2d Sess 12081, 12100, 12104 (1960) (statement of Arthur S. Flemming, Secretary of Health, Education, and Welfare); id at 12123 (statement of George P. Larrick, Commissioner of Food and Drugs); Coleman, 69 Food \& Drug L J at 189 (cited in note 17).

35 See Food and Drug Administration, Department of Health, Education, and Welfare, Drugs; Statement of Ingredients; Prescription Drug Advertisements, 28 Fed Reg 6375,6377 (1963), amending 21 CFR § 1.105(l).

3621 CFR $\$ 202.1(1)(2)$

37 See United States v Harkonen, 2009 WL 1578712, *9-13 (ND Cal). See also William W. Vodra, Nathan G. Cortez, and David E. Korn, The Food and Drug Administration's Evolving Regulation of Press Releases: Limits and Challenges, 61 Food \& Drug L J 623, 624-29 (2006) (describing "how FDA asserted jurisdiction over drug- and devicerelated press releases through its authority over labeling, promotional labeling, and advertising").

38 FDCA $\S 301($ d), 52 Stat at 1042, codified at 21 USC $\S 331$ (d).

39 FDCA $\$ 505$ (a), 52 Stat at 1052, codified at 21 USC $\$ 355$ (a). FDA regulations also declare that a drug is rendered an illegal "new drug" if a company promotes it for an unapproved use. 21 CFR $\$ 310.3(\mathrm{~h})$. added)

40 FDCA $\S 201(\mathrm{p})(1), 52$ Stat at 1042 , codified at 21 USC $\S 321(\mathrm{p})(1)$ (emphasis 
promotion via advertising or oral statements, ${ }^{41}$ which I address below. The new drug provisions are also less useful if the company can argue that the drug is "generally recognized as safe and effective," in which case it is not a new drug at all, or if the drug is a biologic approved under the Public Health Service Act ${ }^{42}$ rather than the FDCA. ${ }^{3}$ Nevertheless, the broad definition of "labeling" helps the FDA argue that products promoted off-label are unapproved new drugs.

\section{B. Misbranding}

More commonly, the FDA relies on the FDCA's misbranding provisions to prosecute off-label promotion, though the statutory case is much more attenuated.

First, off-label promotion that is false or misleading can misbrand a product under FDCA $\S 301(\mathrm{a})$, which prohibits introducing a misbranded product into interstate commerce.44 Section 502(a) provides that a product is misbranded "[i]f its labeling is false or misleading in any particular." 45 Although such an allegation is relatively straightforward as a statutory matter, it can be difficult for the government to prove. Typically, the off-label claim is very much in dispute - scientifically, medically, factually - and so the government must show that the claim misleads. Not surprisingly, then, most of the literature on off-label promotion focuses on cases in which the claim is not necessarily false or misleading. ${ }^{46}$

More frequently, the FDA must make a more attenuated, multistep argument that the product is misbranded. ${ }^{47}$ This argument relies on the statutory requirement that product labeling provide "adequate directions for use." 48 The chain of reasoning requires a fair bit of explanation.

Section 502(f)(1) declares a product misbranded unless its labeling bears "adequate directions for use." ${ }^{99}$ However, this section

\footnotetext{
41 Coleman, 69 Food \& Drug L J at 162 (cited in note 17).

42 Pub L No 78-410, 58 Stat 682 (1944), codified at 48 USC $\$ 201$ et seq.

43 Coleman, 69 Food \& Drug L J at 162 (cited in note 17).

44 FDCA $\S 301(a), 52$ Stat at 1042, codified at 21 USC $\$ 331($ a). The FDA sometimes uses FDCA $\S 301(\mathrm{k})$ for products that are misbranded while being held for sale, after shipment in interstate commerce. 21 USC $\$ 331(\mathrm{k})$. If misbranding is done "with the intent to defraud or mislead," it is subject to additional penalty under 21 USC $§ 333(\mathrm{a})(2)$.

45 FDCA $\S 502(a), 52$ Stat at 1050 , codified at 21 USC $\S 352(a)$.

46 See, for example, Coleman, 69 Food \& Drug L J at $162 \mathrm{n} 2$ (cited in note 17).

47 Consider FDCA $\S 502$, 52 Stat at 1050-51, codified at 21 USC $\S 352$.

48 FDCA $\S 502(\mathrm{f})(1), 52$ Stat at 1051 , codified at 21 USC $\$ 352(\mathrm{f})(1)$.

49 FDCA $\S 502(f)(1), 52$ Stat at 1051 , codified at 21 USC $\S 352(f)(1)$.
} 
exempts drugs and devices for which adequate directions are "not necessary for the protection of the public health." 50 The FDA has interpreted this to exempt all prescription drugs, thus requiring adequate directions only for over-the-counter drugs. ${ }^{51}$ By rule, the FDA has created a series of conditions to qualify for the exemption. ${ }^{52}$

Instead of adequate directions, the FDA expects prescription drugs to provide "adequate information" for safe use by practitioners. ${ }^{53}$ Thus, labeling must include all "indications" for the drug, "including all purposes for which it is advertised or represented." 54 Moreover, the regulations require that any labeling that mentions the uses or dosages for the product may not deviate from the uses and dosages specified in the FDA-approved physician labeling. ${ }^{55}$ Providing "adequate information" for prescribers, then, means including information about "indications, effects, dosages, routes, methods, and frequency and duration of administration." ${ }^{6} 6$ All labeling must use the "same [ ] language and emphasis" and must be "consistent with and not contrary to" the FDA-approved labeling. ${ }^{57}$

Thus, failure to list all indications for the product or failure to use the same language used in the approved labeling can misbrand the product and jeopardize its exemption from the "adequate directions" requirement in $\S 502(\mathrm{f})(1) .58$ In essence, to be exempt, any labeling for prescription drugs must disclose all intended uses; otherwise, the product is misbranded.

Importantly, FDA regulations declare that the manufacturer's intended uses can be gleaned from a variety of sources, including "labeling [ ], advertising [ ], or oral or written statements." " 59 As these regulations make clear, "intended use" is the "objective intent of the persons legally responsible for the labeling" of the product, and can be determined by their "expressions," including "labeling claims, advertising matter, or oral or written statements by such persons or their representatives." 60 Objective

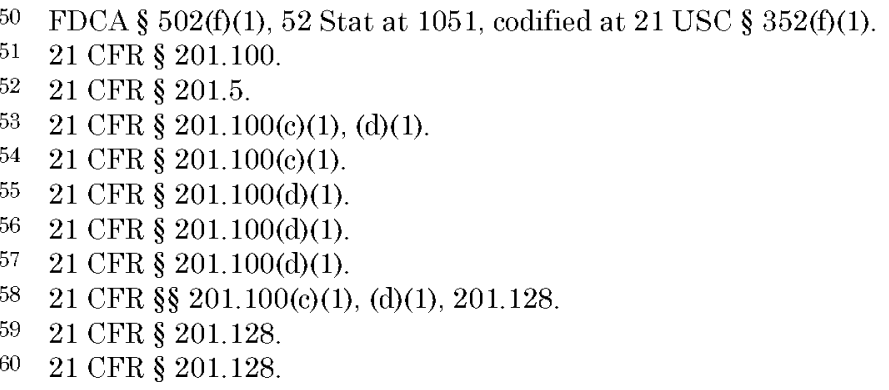


intent can also be determined "by the circumstances surrounding the distribution" of the product. ${ }^{61}$ Thus, a company's knowledge that its product is "offered and used for a purpose for which it is neither labeled nor advertised" can be evidence of intent. ${ }^{2}$

This "incorporation-by-reference theory" ${ }^{6}$ creates a catch-22, or what observers call the "squeeze play" against off-label promotion: companies that do not disclose off-label uses in their physician labeling misbrand the product by failing to provide adequate directions for laypersons or adequate information for prescribers; but companies that try to amend their labeling to provide such information misbrand the product or cause the product to be an unapproved new drug. ${ }^{64}$

This interpretation "encountered little resistance from the courts," and "may be the most powerful tool that FDA has against most forms of off-label promotion." 65 The FDA developed this argument shortly after Congress passed the FDCA in $1938 .{ }^{66}$ It began as a rule to require labeling to include adequate directions for indications claimed in advertising. ${ }^{67}$ In the 1938 Act, Congress had chosen to vest authority over advertising for FDA-regulated products with the Federal Trade Commission rather than the FDA, over the FDA's bitter opposition. 68 Thus, the statutory basis for the FDA's 1938 regulation was questionable. In fact, it took almost a decade for the FDA to test it in court. ${ }^{69}$

A skeptical Justice Department asked the FDA to explain its authority. ${ }^{70}$ The response, though unavailable, most likely relied on the idea held by FDA officials then that the agency would not be challenging advertising claims themselves, but instead would use those claims as evidence to challenge deficiencies in the product's labeling (the failure to include adequate directions). ${ }^{71} \mathrm{FDA}$

\footnotetext{
6121 CFR $\$ 201.128$.

6221 CFR $\$ 201.128$.

63 See Coleman, 69 Food \& Drug L J at 228 (cited in note 17).

64 See id at 196.

65 Id at 193.

66 Food and Drug Administration, Promulgation of Regulations under the Federal Food, Drug, and Cosmetic Act and Repeal of Certain Regulations Heretofore Promulgated Thereunder, 3 Fed Reg 3161, 3167 (1938). The FDA formalized the "intended use" doctrine in 1944. Food and Drug Administration, Regulations for the Enforcement of the Federal Food, Drug, and Cosmetic Act, 9 Fed Reg 12255, 12256-57 (1944).

673 Fed Reg at 3167 (cited in note 66 ).

68 Coleman, 69 Food \& Drug L J at 171-76 (cited in note 17). Congress reversed this position in 1962. See generally Drug Amendments of 1962, Pub L No 87-781, 76 Stat 780.

69 Coleman, 69 Food \& Drug L J at 194 (cited in note 17).

70 Id at 194 \& n 208 (citing a 1946 letter from Assistant Attorney General Theron L. Caudle to Assistant General Counsel of the Federal Security Agency Daniel P. Willis).

71 Id at 195 (cited in note 17).
} 
officials explained that before the 1938 regulation was published, the agency had sent a draft to the House of Representatives legislative counsel, "who apparently had no objections, thus demonstrating that the regulation was consistent with congressional intent." 72 A few years later, a court accepted the FDA's argument that "adequate directions" focused on labeling deficiencies rather than impermissible advertising claims. ${ }^{79}$

Eventually, the FDA pushed the theory even further, arguing that a series of health lectures for a company could be used as evidence of intent. ${ }^{74}$ The agency argued that the company misbranded the products by failing to include adequate directions for the uses discussed during the lectures. ${ }^{75}$ Because the lectures could not be "labeling," the FDA argued that they were relevant only to show intended use, and that the drugs were misbranded only because their labeling failed to state their uses as required by the Act. ${ }^{76}$ The court agreed. ${ }^{77}$

Emboldened by these victories, the FDA amended the regulation to require adequate directions not only for uses suggested in advertising, but also for uses suggested in other contexts. The modern "squeeze play," then, derives from the FDA's very early aggressive interpretation of the Act, which was driven by its initial lack of jurisdiction over advertising. ${ }^{78}$

\section{OfF-LABEL Promotion VIA ADVERTISING}

If off-label promotion occurs via advertising rather than labeling, the FDA can allege violations of multiple sections of the FDCA - again, none of which explicitly prohibits such promotion. First, $\S 303(\mathrm{~g})$ of the Act prohibits direct-to-consumer advertising that is false or misleading, ${ }^{79}$ which might form the basis for a straightforward complaint. But, as noted above, such claims are difficult to prosecute if they are at all subject to unsettled or conflicting scientific evidence.

\footnotetext{
72 Id.

73 See Alberty Food Products v United States, 194 F2d 463, 464 (9th Cir 1952)

74 See Coleman, 69 Food \& Drug L J at 194 (cited in note 17).

75 Id at 196 (citing a 1947 letter from Acting Assistant General Counsel, Federal Security Agency, Alvin M. Loverud to Assistant US Attorney Harry C. Blanton).

76 Id (citing a 1947 letter from Acting Assistant General Counsel, Federal Security Agency, Alvin M. Loverud to Assistant US Attorney Harry C. Blanton).

77 United States v 150 Packages, etc, Labeled in Part Bush Mulso Tablets, 83 F Supp 875,880 (ED Mo 1947).

78 Coleman, 69 Food \& Drug L J at 196 (cited in note 17).

79 Food and Drug Administration Amendments Act of $2007 \S 503(\mathrm{~g})$, Pub L No 110 85,121 Stat 823,940 , amending $\S 303(\mathrm{~g})$ of the FDCA and codified at $21 \mathrm{USC} \S 333(\mathrm{~g})$.
} 
Second, $\$ 502(n)$ of the Act authorizes the FDA to ensure that prescription drug advertisements are not misbranded. ${ }^{80}$ This section does not mention off-label promotion; instead, it requires advertisements to give either a "brief summary relating to side effects, contraindications, and effectiveness," 81 or in the case of television or radio ads provide a "major statement" of side effects and contraindications. ${ }^{82}$ The word "effectiveness" in $\$ 502(\mathrm{n})$ can be read as requiring that advertisements briefly summarize the approved indications. Indeed, the FDA by rule declares that an advertisement for a prescription drug is false, misleading, lacks fair balance, or otherwise violates $\$ 502(\mathrm{n})$ if it "[c]ontains a representation or suggestion, not approved or permitted for use in the labeling, that a drug is better, more effective, [or] useful in a broader range of conditions or patients . . than has been demonstrated by substantial evidence or substantial clinical experience." ${ }^{83}$ More directly, the rule also prohibits prescription drug advertisements from recommending or suggesting "any use that is not in the labeling accepted in [the] new-drug application or supplement." 84

Thus, as with the regulations prohibiting off-label promotion in labeling, the regulations prohibiting off-label promotion in advertising derive from broadly worded statutory text that is not at all explicit on the point. ${ }^{85}$

\section{OfF-Label Promotion via Oral Statements}

Finally, if the off-label claims are made via oral statements, then the FDA must use even different statutory logic. As with claims made via labeling, the FDA uses a complicated squeeze play, relying on the adequate directions requirement in $\$ 502(f)(1)$. Again, the squeeze play puts companies in a catch-22: one can misbrand a product by failing to provide adequate directions for laypersons or adequate information for prescribers, or

80 Drug Amendments of $1962 \S 131,76$ Stat 780,791 , codified at 21 USC $\$ 352(\mathrm{n})$

81 Drug Amendments of $1962 \S 131,76$ Stat at 791-92, codified at 21 USC $\S 352(\mathrm{n})$

82 FDA Amendments Act of $2007 \S 301,121$ Stat at 940, codified at 21 USC $\$ 352(\mathrm{~g})$.

$8321 \mathrm{CFR} \S 202.1(\mathrm{e})(6)(\mathrm{i})$.

$8421 \mathrm{CFR} \S 202.1(\mathrm{e})(4)(\mathrm{i})(\mathrm{a})$.

85 Some argue that the FDA's expansive interpretation of "labeling" has erased any meaningful distinction between advertising and labeling. See, for example, Coleman, 69 Food \& Drug L J at 191-92 (cited in note 17). Sometimes, the FDA alleges violations of both sets of regulations. See, for example, Thomas Abrams, Director of the Division of Drug Marketing, Advertising, and Communications, FDA, Letter to Reinhard Franzen, President and Chief Executive Officer, Bayer HealthCare Pharmaceuticals, Inc *1 (Oct 3 , 2008), archived at http:/perma.cc/WX4R-HYUE. 
one can amend the labeling to include off-label uses and thus misbrand the product or create an unapproved new drug. ${ }^{86}$

Again, the intended use doctrine ${ }^{87}$ allows the FDA to take action against marketers based on the content of their communications, without necessarily asserting jurisdiction over the communications themselves, ${ }^{8}$ a distinction recently rejected by the Second Circuit. ${ }^{89}$ FDA regulations extend this logic to oral statements, even though such statements are not "written, printed, or graphic matter" that would qualify as "labeling." 90 Indeed, the FDA rule that defines "adequate directions" makes clear that intended uses include uses suggested orally. ${ }^{91}$ As such, FDA warning letters have objected to oral presentations by sales representatives in physicians' offices, at exhibit booths, or before formulary boards. ${ }^{92}$

An important caveat here is First Amendment doctrine. The Second Circuit recently sustained a First Amendment defense by Alfred Caronia, a sales representative who had been convicted for promoting the narcolepsy drug Xyrem for unapproved indications such as fibromylagia, muscle disorders, and chronic pain. ${ }^{93} \mathrm{He}$ was surreptitiously recorded discussing these and several other off-label uses for Xyrem. The court found that the FDA had "treated promotional speech as more than merely evidence of a drug's intended use," and had "construed the FDCA to prohibit promotional speech as misbranding itself." ${ }^{4}$ Apparently, this is a matter of degree- the Second Circuit emphasized the extent to which the government objected to Caronia's speech in its briefs and during trial, in comparison to how little it focused on the statutory violation. ${ }^{95}$ The dissent argued that drug regulation has relied on intended use for over a century, and that courts have used

\footnotetext{
86 See Peter Barton Hutt, Richard A. Merrill, and Lewis A. Grossman, Food and Drug Law 930-31 (Foundation 4th ed 2014).

8721 CFR $\$ 201.128$ (defining "intended uses" for drugs); 21 CFR $\$ 801.4$ (defining "intended uses" for devices).

88 Vodra, Cortez, and Korn, 61 Food \& Drug L J at 627 (cited in note 37).

89 United States v Caronia, 703 F3d 149, 155 (2d Cir 2012).

90 FDCA $\S 201(\mathrm{~m}), 52$ Stat at 1041 , codified at 21 USC $\S 321(\mathrm{~m})$.

$91 \quad 21$ CFR $\$ 201.5(\mathrm{a})$.

92 Vodra, Cortez, and Korn, 61 Food \& Drug L Jat 627 (cited in note 37) (citing letters).

93 Caronia, 703 F3d at 152.

94 Id at 155 .

95 Id at 160-62 (noting that "[t]he government never suggested, for example, that Caronia conspired to place false or deficient labeling on a drug" and that "the government prosecuted Caronia for his promotion and marketing efforts" and holding that "the government [ ] prosecute[d] Caronia for his speech").
} 
oral representations as evidence of intent for nearly as long. ${ }^{96}$ Thus, after United States v Caronia, ${ }^{97}$ oral statements may have additional cover from FDA regulation.

\section{APPLYING TOOLS OF CONSTRUCTION TO THE FDCA}

The FDA clearly views off-label promotion as evidence of statutory violations. But how does the FDA's position fare when subjected to the tools of statutory construction? Almost no one has seriously undertaken the task. The Second Circuit's statutory analysis in Caronia is perfunctory, ${ }^{98}$ though later decisions have latched onto it. 99 Because companies typically challenge the FDA's prohibition on First Amendment rather than statutory grounds, most opinions logically focus on free speech doctrine. One goal of this Essay, then, is to provide a more concerted statutory analysis.

\section{A. Chevron Deference}

As a threshold matter, the FDA's interpretation of the FDCA, a statute the agency is charged with administering, would be subject to Chevron deference from courts. ${ }^{100}$ And under Chevron U.S.A. Inc $v$ Natural Resources Defense Council, Inc, ${ }^{101}$ courts must defer to an agency's construction of an ambiguous statute if the interpretation is reasonable. ${ }^{102}$ For the sake of space, and to avoid duplicative analysis, I address the two-step test under Chevron as a single inquiry: Is the FDA's interpretation of the Act reasonable? ${ }^{103}$

\footnotetext{
96 Id at 169-70 (Livingston dissenting), citing Pure Food and Drugs Act of 1906, 34 Stat 768. See also United States v Eleven Cartons of Drug Labeled in Part "Vapex", 59 F2d 446, 448 (D Md 1932); V.E. Irons, Inc v United States, 244 F2d 34, 44 (1st Cir 1957).

103 The Chevron two-step first asks whether Congress "has directly spoken to the precise question at issue," and then, if it has not, asks whether the agency's interpretation is "based on a permissible construction of the statute." Id. Some scholars argue that Chevron is really one step. See generally Matthew C. Stephenson and Adrian Vermeule, Chevron Has Only One Step, 95 Va L Rev 597 (2009).
} 


\section{B. The Text}

The text of the FDCA, as detailed above, broadly prohibits misbranding and introducing unapproved new products into interstate commerce, 104 and broadly defines "labeling," which is used to determine both types of violations. ${ }^{105}$ Although these provisions do not expressly prohibit off-label promotion, these and other provisions do broadly authorize the FDA to establish the conditions under which drugs and devices may be legally marketed. ${ }^{106}$ Indeed, former FDA Chief Counsel Peter Barton Hutt once declared that "the Act must be regarded as a constitution" that "establishes a set of fundamental objectives . . . without attempting to specify every detail of regulation." 107 Although courts have questioned in egregious cases how far this principle can stretch, 108 they have generally confirmed the FDA's broad authority.

Moreover, contrary to the Second Circuit's very cursory analysis, ${ }^{109}$ the FDCA is not completely silent on off-label marketing. Multiple sections contemplate or assume a ban on it. Under a section titled "Practice of Medicine," the Act states that "[n]othing in this chapter shall be construed to limit or interfere with the authority of a health care practitioner to prescribe or administer any legally marketed device to a patient for any condition or disease." ${ }^{110}$ Thus, the FDCA specifically contemplates offlabel prescribing of medical products. However, the same provision continues: "This section shall not limit any existing authority of the Secretary to establish and enforce restrictions on the sale or distribution, or in the labeling, of a device. . . Further, this section shall not change any existing prohibition on the promotion of unapproved uses of legally marketed devices." ${ }_{111}$ Thus, Congress recognized in the text of the FDCA itself an "existing prohibition" against off-label promotion.

104 See Part II

105 See Part II

106 Food and Drug Administration Modernization Act of 1997 (FDAMA) $§ 406$, Pub L No 105-115, 111 Stat 2296, 2369, codified at 21 USC $\$ 393(b)$.

107 Peter Barton Hutt, Philosophy of Regulation under the Federal Food, Drug and Cosmetic Act, 28 Food Drug Cosmetic L J 177, 178 (1973).

108 See, for example, FDA v Brown \& Williamson Tobacco Corp, 529 US 120, 155-56 (2000) (ruling that the FDCA does not authorize the FDA "to regulate tobacco products as customarily marketed").

109 See Caronia, 703 F3d at 154-55.

110 FDAMA $\S 214,111$ Stat at 2348 , codified at 21 USC $\S 396$.

111 FDAMA $\$ 214,111$ Stat at 2348, codified at 21 USC $\$ 396$ (emphasis added). This section was part of the 1938 Act and was amended in 1997 and 2009. See FDAMA $§ 214$, 
The FDCA also nods to off-label use in another section authorizing unapproved uses of approved products in emergencies. ${ }^{112}$ Here, the statute defines "unapproved use of an approved product" as use of a product that is "is approved, licensed, or cleared under [the FDCA], but which use is not under such provision an approved, licensed, or cleared use of the product." 113 The section then sets forth extensive criteria for the FDA to grant authorization for emergency off-label uses, ${ }^{114}$ including limited advertising and promotion for such. ${ }^{115}$ This is strong evidence that Congress read the Act as empowering the FDA to prohibit offlabel promotion.

\section{Whole Act Rule}

Although there are dozens of canons of construction, ${ }^{116}$ a few seem especially pertinent here. First, the "whole act rule" and its corollaries tell courts to construe statutory provisions in light of the entire statute, rather than in isolation. ${ }^{117}$ Courts should avoid constructions that are inconsistent with the overall structure of the statute, with other provisions, or with subsequent amendments. ${ }^{118}$

When considering the FDCA as a whole, one can find dozens of provisions that would make little sense if off-label promotion were widely permissible. In particular, the "new drug" provisions in $\S 505,{ }^{119}$ which span dozens of pages and include dozens of subsections, would be seriously undermined without such a prohibition. Section 505 creates a comprehensive system for manufacturers to conduct clinical trials and submit "substantial evidence that the drug will have the effect it purports or is represented to

\footnotetext{
111 Stat at 2348; Family Smoking Prevention and Tobacco Control Act $\$ 101(b)(2)$, Pub L No 111-31, 123 Stat 1776,1784 (2009).

11221 USC $\$ 360 \mathrm{bbb}-3$.

11321 USC $\$ 360$ bbb-3(a)(2)(B), (4)(E).

11421 USC $\$ 360 \mathrm{bbb}-3$.

11521 USC $\$ 360 \mathrm{bbb}-3(\mathrm{e})(4)$.

116 See generally Antonin Scalia and Bryan A. Garner, Reading Law: The Interpretation of Legal Texts (Thomson/West 2012). See also William N. Eskridge Jr, Philip P. Frickey, and Elizabeth Garrett, Cases and Materials on Legislation: Statutes and the Creation of Public Policy, Appx B at 19-41 (Thomson/West 4th ed 2007).

117 See, for example, Gonzales v Oregon, 546 US 243, 273-74 (2006) (rejecting an interpretation of the Controlled Substances Act by the attorney general in part because the interpretation failed to consider the Act as a whole).

118 See, for example, Ledbetter v Goodyear Tire \& Rubber Co, 550 US 618, 629-30 (2007) (interpreting the statute of limitations in Title VII of the Civil Rights Act in light of the integrated enforcement scheme created by Title VID); Gonzales, 546 US at 257-58.

119 FDCA $\S 505,52$ Stat at 1052 , codified at 21 USC $\S 355$.
} 
have under the conditions of use prescribed, recommended, or suggested in the proposed labeling thereof." 120 The statute defines "substantial evidence" as "adequate and well-controlled investigations." 121 Given that most off-label claims are supported by something far less than "adequate and well-controlled investigations," interpreting the Act to permit such promotion would undermine "supplemental applications," which are mentioned numerous times in the statute. Indeed, the FDCA includes forty-five separate sections that refer to "new drugs" and seventeen sections that refer to "supplemental applications." ${ }^{22}$ Moreover, massive parts of the Code of Federal Regulations are predicated on these authorities and have been in use for decades. ${ }^{123}$ Thus, these statutory provisions endow the FDA with important gatekeeping authority over new drugs, including the conditions under which they can be legally marketed. ${ }^{124}$

That said, it is somewhat odd that the prohibition against offlabel promotion is buried in the statutory requirement that products must provide adequate directions for use. ${ }^{125}$ But, again, this is most likely a remnant of the original struggle by the FDA to overcome limits in its legal authority over drug advertising. ${ }^{126}$

\section{Avoiding Absurdity}

Another canon invoked by courts is to avoid statutory interpretations that create absurd results. ${ }^{127}$ One can argue that the FDCA should be interpreted to prohibit off-label promotion because it would be absurd not to. The most salient feature of FDA regulation over pharmaceuticals is its gatekeeping authority-the authority to require manufacturers to conduct clinical trials and show "substantial evidence" that a drug is safe and effective for its intended uses. 128 The new drug approval system,

\footnotetext{
120 Drug Amendments of $1962 \S 102(\mathrm{c}), 76$ Stat at 781, codified at 21 USC $\S 355(\mathrm{~d})$

121 Drug Amendments of $1962 \S 102$ (c), 76 Stat at 781, codified at 21 USC $\$ 355$ (d).

122 This count is based on a search performed on Chapter 9 of Title 21 of the US Code (the FDCA).

123 See, for example, $21 \mathrm{CFR}$ Pts $310,312,314.21 \mathrm{CFR} \S 314.70$ (a)(1)(i) establishes criteria for filing supplemental applications to seek FDA approval for "each change in each condition established in an approved application."

124 See Carpenter, Reputation and Power at 608-10 (cited in note 2).

125 Coleman, 69 Food \& Drug L J at 198 (cited in note 17).

126 Id.

127 See, for example, Green v Bock Laundry Machine Co, 490 US 504, 509-11 (1989)

(finding that Federal Rule of Evidence 609(a)(1) could not be read literally, as it would create "odd" or absurd results).

$12821 \mathrm{USC} \$ \S 355,393(\mathrm{~b})(2)(\mathrm{B})$.
} 
then, is the centerpiece of pharmaceutical regulation. ${ }^{129}$ Indeed, when the government's interest in prohibiting off-label claims is at issue, typically in First Amendment cases, ${ }^{130}$ the FDA often argues that its entire drug approval scheme relies on the ability to identify intended uses. Without it, companies would have little incentive to conduct clinical trials and file supplemental new drug approval applications for new uses. Companies instead would have an incentive to seek the narrowest and least controversial uses for initial approval, then easily expand the product's indications through aggressive marketing. Unsubstantiated claims would flood the drug market, much like they do the market for dietary supplements, ${ }^{131}$ which are not subject to premarket review. It is no accident, then, that the government's interest in regulating off-label promotion and preserving the drug approval system is virtually always found to be "substantial" for First Amendment purposes. ${ }^{132}$

The prohibition against off-label promotion is thus key to the integrity of the drug approval scheme that the FDCA constructs so carefully. ${ }^{133}$ Without evidence of intended use, "this regulatory machinery for protecting patients from unsafe and ineffective drugs would be drastically impaired." 134 It would also draw into question not only the century-old intended use doctrine, but also the very definitions of "drug" and "device," which also depend on intent. ${ }^{135}$ Moreover, if the FDA knew that once a drug was approved, it could be legally marketed for any use, the agency might weigh the benefits and risks less charitably in the first instance. ${ }^{136}$ Surely this must be an absurd result.

\section{E. The Avoidance Canon}

The Second Circuit in Caronia invoked the canon of constitutional avoidance to construe the FDCA as not prohibiting "mere

129 Brown \& Williamson, 529 US at 133; Carpenter, Reputation and Power at 608 (cited in note 2).

130 See, for example, Washington Legal Foundation v Henney, 202 F3d 331, 332-34 (DC Cir 2000).

131 See Paul A. Offit, Do You Believe in Magic? The Sense and Nonsense of Alternative Medicine 64-107 (HarperCollins 2013).

132 See, for example, Caronia, 703 F3d at 165-66; Thompsonv Western States Medical Center, 535 US 357,369 (2002)

133 See Caronia Brief at *61 (cited in note 18 ).

134 Id at *61-62.

13521 USC $\$ 321(\mathrm{~g})(1)$, (h).

136 See, for example, Caronia, 703 F3d at 179 (Livingston dissenting) 
off-label promotion," on the logic that "such a construction would raise First Amendment concerns." ${ }^{137}$ The avoidance canon directs courts to choose interpretations that would not render the statute unconstitutional or raise serious questions about its constitutionality. ${ }^{138}$ On first glance, because the Second Circuit indeed found a First Amendment violation, it is not surprising that the court invoked the canon. But on second glance, it is curious to rely heavily on the avoidance canon here. For decades, courts have construed the FDCA in light of First Amendment limitations. ${ }^{139}$ Moreover, Caronia was an as-applied challenge rather than a facial challenge. The court was asked whether the FDA's policy, applied to Caronia, violated his First Amendment rights, not whether the FDCA permitted the FDA's policy as a threshold matter. ${ }^{140}$ Thus, although technically not prevented from relying on the avoidance canon, it seems bizarre to invoke it without considering other tools of construction.

\section{F. Congressional Approval or Acquiescence}

A complementary argument is that the FDA's interpretations are old and well-established, yet Congress has never seen fit to amend the statute otherwise, suggesting Congress has acquiesced to the FDA's position. ${ }^{141}$ Congress has amended the FDCA more than one hundred times since 1938, ${ }^{142}$ and not once did it feel the need to clarify or reject the prohibition against off-label promotion.

If one is not persuaded that Congress can endorse the FDA's position by inaction, then consider past congressional action. In 1997, Congress affirmed the FDA's position when it passed the

137 Id at 160

138 See, for example, Edward J. DeBartolo Corp v Florida Gulf Coast Building \& Construction Trades Council, 485 US 568, 575 (1988) (refusing to interpret the National Labor Relations Act as prohibiting unions from distributing handbills in certain circumstances, as it would raise First Amendment free speech problems).

139 For an early example, see United States v Article of Drug Designated B-Complex Cholinos Capsules, 362 F2d 923, 927 (3d Cir 1966) (rejecting a manufacturer's argument that the FDA's use of statements as evidence of intent was "an expansion of the power and jurisdiction of the [FDA] into areas of free speech").

140 Caronia, 703 F3d at 162-69.

141 For an example of a similar argument, see Bob Jones University v United States, 461 US 574, 599-602 (1983) (finding a strong case that Congress acquiesced to the IRS's interpretation of the Internal Revenue Code). But see Brown \& Williamson, 529 US at 155 (finding that Congress did not acquiesce to the FDA's new position on whether the FDCA, unamended, granted it authority to regulate tobacco products).

142 Hutt, Merrill, and Grossman, Food and Drug Law at 11 (cited in note 86). 
Food and Drug Administration Modernization Act of 1997143 (FDAMA). Section 401 allowed manufacturers to disseminate certain information on off-label uses under carefully prescribed circumstances, "[n]otwithstanding sections 301(d), 502(f), and 505" of the FDCA.144 The clear implication was that these three sections otherwise prohibited off-label promotion. FDAMA $\S 401$ thus exempted qualifying materials from being considered as evidence of a new intended use. ${ }^{145}$ Moreover, the law declared that dissemination of qualifying materials "shall not be considered . . . as labeling, adulteration, or misbranding." 146 Thus, through duly enacted legislation, Congress assumed that the FDCA prohibited off-label promotion, and in fact crafted a narrow exemption from the prohibition. The only "prohibited act" FDAMA added to the FDCA was to declare it a misbranding violation to disseminate off-label information in violation of the new exemption. ${ }^{147}$

\section{CONCLUSION}

The FDA's "prohibition" against off-label promotion has been questioned numerous times, but few have engaged in a rigorous analysis of its statutory foundation, particularly applying tools of construction. Applying these tools and engaging in a close textual analysis reveals a complex but compelling statutory case. Almost eighty years ago, Congress endowed the FDA with broad powers via a broadly worded statute. For just as long, both the agency and the courts have interpreted those powers accordingly to address emerging problems. Congress, in turn, has incorporated these interpretations, including the functional ban on off-label promotion. As a result, subsequent amendments to the FDCA either assume or contemplate a prohibition against off-label promotion. This long evolution has created a complex statutory basis for prohibiting off-label promotion, but a solid basis nonetheless.

\footnotetext{
143 Pub L No 105-115, 111 Stat 2296.

144 FDAMA $\S 401$ (a), 111 Stat at 2356-58, expired in 2006, citing also Public Health Service Act $\$ 351$, Pub L No 78-410, 58 Stat 682, 702 (1944). These amendments were subject to a statutory sunset in 2006. FDAMA $\S 401(\mathrm{e}), 111$ Stat at 2364. Section 401, of course, was invalidated on First Amendment grounds in Washington Legal Foundation v Friedman, 13 F Supp 2d 51 (DDC 1998), until the FDA interpreted it as a "safe harbor" rather than a legal prohibition. Henney, $202 \mathrm{~F} 3 \mathrm{~d}$ at 335.

145 FDAMA § 401(a), 111 Stat at 2363.

146 FDAMA § 401(a), 111 Stat at 2363.

147 FDAMA § 401(b), 111 Stat at 2364
} 